\title{
Editorial
}

\section{Water Resources Management Models for Policy Assessment}

\author{
Luis Garrote (iD)
}

Citation: Garrote, L. Water Resources Management Models for Policy Assessment. Water 2021, 13, 1063. https://doi.org/10.3390/ w13081063

Received: 7 April 2021

Accepted: 9 April 2021

Published: 13 April 2021

Publisher's Note: MDPI stays neutral with regard to jurisdictional claims in published maps and institutional affiliations.

Copyright: (C) 2021 by the author. Licensee MDPI, Basel, Switzerland. This article is an open access article distributed under the terms and conditions of the Creative Commons Attribution (CC BY) license (https:// creativecommons.org/licenses/by/ $4.0 /)$.
Department of Civil Engineering, Hydraulics, Energy and Environment, Universidad Politécnica de Madrid, 28040 Madrid, Spain; l.garrote@upm.es

Water resources management models support a variety of research applications, including the assessment of water availability [1], the allocation of water among competing uses [2], the evaluation of system performance [3,4], the identification of optimal system expansion [5], and the definition of suitable operating strategies [6]. System analysis tools, like simulation and optimization, have been enriched with novel modelling concepts drawn from social sciences [7], economic analysis [8], conflict resolution [9], agent-based systems [10], and game theory [11], among others. The field has evolved from a traditional emphasis on cost-benefit analysis in water resource project investments to a wider scope that includes environmental implications, stakeholder concerns, social welfare, and human dimensions [12].

This Special Issue of Water integrates a collection of research papers that develop or apply water resources management models for policy identification and assessment. Active research has been conducted to address the challenge of developing integrated modelling frameworks to provide quantitative evidence for policymakers on water management issues. The compilation presented here covers a wide range of topics and methodologies applied across the world, from a local to continental scope. It illustrates open challenges in water resources management, like quantitative assessment of policy impacts, trade-off analyses, understanding the water-energy-food-environment nexus, collaborative model development, stakeholder engagement, formalizing social interactions, or improving the theoretical understanding of complex adaptive systems. This issue is therefore a representation of research areas that have emerged from the origins of water resource systems analysis seeking to improve the way water policy is formulated and implemented.

The contributions to the Special Issue may be classified into four major topics: water availability and accessibility, management of water infrastructure, environmental concerns, and social and economic issues. Contributions in the first group focus on the estimation of water availability under different climate and policy scenarios. Two papers are focused on Europe and two are focused on China. The paper by Sordo-Ward et al. [13] presented a regional assessment of future water availability in Europe. They applied a high-resolution model to produce detailed maps of water availability in European rivers and evaluated model and scenario uncertainties under different climate projections. The work presented in [14] was specifically focused on the role of reservoir storage to enhance resilience to climate change. The authors studied 16 major river basins in Southern Europe and found that increased storage capacity attenuated the reduction of water availability and reduced its uncertainty under climate change projections. Li et al. [15] evaluated five spatial factors to obtain a water accessibility index in Southwest China. They produced a spatial pattern and compared water accessibility and water demand at the county level. As a result of their analysis, the authors provided policy recommendations to correct the imbalance. Finally, Wang et al. [16] studied the water-carrying capacity of the Chang-Ji region in Northeast China. They applied techniques such as the fuzzy comprehensive evaluation method, gray correlation analysis, and multiple linear regression models to evaluate water-carrying capacity under different social development plans, identified critical issues, and provided suggestions to allow for a sustainable development of the economy in the region. 
The second topic deals with models intended to provide support for management policies for water infrastructure. The paper by Rubio-Martin et al. [17] presented an application of system dynamics for the strategic planning of drought management in a river basin located in Southeast Spain. The authors proposed a system state index that is used to trigger dynamic reservoir operating rules, policies, and drought management strategies. They argued that application of their decision support system may lead to a substantial reduction of the economic impact of droughts in the basin. Gabriel-Martin et al. [18] aimed at solving conflicts that arise in the operation of multipurpose reservoirs. Their technical contribution is a model that maximizes reservoir yield subject to constraints imposed by hydrological dam safety and downstream river safety. They produced a set of Pareto optimal configurations that may be used by policymakers to emphasize water availability or flood protection. Bejarano et al. [19] offered a computational tool intended to summarize data on sub-daily streamflow into manageable, comprehensive, and ecologically meaningful metrics, which can be used to qualify and quantify flow alteration. This tool may be used by policymakers to evaluate the potential ecological consequences of the hydrological alteration produced by water infrastructure. The contribution by Martin-Candilejo et al. [20] is focused on energy efficiency. They proposed a novel method to account for energy costs associated to water pumping in the design and operation of water supply systems.

Water quality is the major focus of the third topic, which deals with environmental concerns. Xie et al. [21] reported on the experience of implementing the nation-wide freshwater health evaluation in China. They proposed a new indicator framework combining ecosystem integrity with non-ecological performance with the objective of improving water governance. The result of their work is directly policy-relevant because it will be integrated into a new national standard. Salehi et al. [22] evaluated the pollutant discharge characteristics for 12 facilities in an industry sector in the United States. They applied principal component analysis to water quality parameters and developed water quality indexes to monitor water quality fluctuations. They characterized stormwater quality variations among studied facilities and seasons, concluding with suggestions for future changes for decision makers. The work by Duan et al. [23] focused on background pollutants and their influence on water quality management and assessment methods in China. The authors argue that it is unreasonable to use a uniform standard to evaluate water quality across the country. They defined a suitable pollutant yield coefficient by coupling an export coefficient model with a mechanistic model. Based on their results, they proposed a more reasonable sewage discharge limit and water quality evaluation method. Best management practices to control water pollution were analyzed in [24]. The authors evaluated the performance of three types of pollution control measures on dissolved nitrogen by coupling an improved watershed model with a multi-objective optimization algorithm. Their optimization model system could assist decision-makers in selecting the most appropriate measures for pollution control in a watershed. Wang et al. [25] proposed an index system to evaluate the degree of coordination between economic development and infrastructure construction in a sponge city in China. They studied the spatial statistical pattern of coordination and concluded that the problems due to inadequate coordination were prominent in the region. They suggested a stronger emphasis on the construction of green infrastructure.

The fourth topic is related to social and economic issues. Lima-Quispe et al. [26] discussed river basin planning in Bolivia from the wider perspective of regional planning. They tackled the problems of coordinating watershed planning with other planning units and integrating watershed management with water resources management. The authors proposed the novel technique of robust decision support to help stakeholders discern positive and negative interactions of interventions, use spatially explicit indicators, and identify adequate management strategies. Li et al. [27] explored the applicability of China's policy based on water saving contracts by risk assessment. Overall risk was found to be low, but they showed concern for some potential risk factors, such as audit, financing, and payment risk. Feria-Dominguez et al. [28] analyzed the impact of a severe drought on the Brazilian stock market. They found statistical evidence of financial impact caused by the declaration 
of drought among agri-food firms, particularly in those companies that shell perishable products. Shen et al. [29] studied the impact of tourism on the sustainable development of a reservoir in China. They applied different analytical techniques to process hundreds of questionnaires filled by the local population. In their conclusions, they found that stakeholders were very critical of the consequences of tourism development in the region and provided suggestions to mitigate the negative impacts. Santasusagna Riu et al. [30] also used questionnaires to analyze the management of urban public services in the internal border area between two Spanish regions. Based on their analysis of the replies, they concluded that there are deficiencies to correct and suggested enhanced cooperation across the border to improve priority urban public services.

This Special Issue is a compilation of 18 contributions that offer a wide perspective of the potential of water resources management models for policy assessment. The papers focus on a diversity of topics, geographical locations, spatial scales, and methodologies that illustrate successful case studies of science inspiring policy. This work is offered as an asset for researchers and policymakers.

Funding: This research received no external funding.

Acknowledgments: The Guest Editor wishes to thank the authors for their relevant contributions to the Special Issue and to the anonymous reviewers for their constructive comments and their dedication. Special thanks to the editorial managers who worked hard to speed up the handling of the manuscripts submitted to this Special Issue. Their help is gratefully acknowledged.

Conflicts of Interest: The author declares no conflict of interest.

\section{References}

1. Alcamo, J.; Doll, P.; Henrichs, T.; Kaspar, F.; Lehner, B.; Rösch, T.; Siebert, S. Development and testing of the WaterGAP 2 global model of water use and availability. Hydrol. Sci. 2003, 48, 317-337. [CrossRef]

2. Letcher, R.A.; Jakeman, A.J.; Croke, B.F.W. Model development for integrated assessment of water allocation options. Water Resour. Res. 2004, 40, W05502. [CrossRef]

3. Hashimoto, T.; Stedinger, J.R.; Loucks, D.P. Reliability, Resiliency, and Vulnerability Criteria for Water-Resource System Performance Evaluation. Water Resour. Res. 1982, 18, 14-20. [CrossRef]

4. Zou, H.; Liu, D.; Guo, S.; Xiong, L.; Liu, P.; Yin, J.; Zeng, Y.; Zhang, J. Shen, Y Quantitative assessment of adaptive measures on optimal water resources allocation by using reliability, resilience, vulnerability indicators. Stoch. Environ. Res. Risk Assess. 2020, 34, 103-119. [CrossRef]

5. Girard, C.; Rinaudo, J.; Pulido-Velazquez, M.; Caballero, Y. An interdisciplinary modelling framework for selecting adaptation measures at the river basin scale in a global change scenario. Environ. Model. Softw. 2015, 69, 42-54. [CrossRef]

6. Labadie, J.W. Optimal Operation of Multireservoir Systems: State-of-the-Art Review. J. Water Resour. Plan. Manag. 2004, 130, 93-111. [CrossRef]

7. Purkey, D.R.; Huber-Lee, A.; Yates, D.N.; Hanemann, M.; Harrod-Julius, S. Integrating a Climate Change Assessment Tool into Stakeholder-Driven Water Management Decision-Making Processes in California. Water Resour. Manag. 2007, 21, 315-329. [CrossRef]

8. Harou, J.J.; Pulido-Velazquez, M.; Rosenberg, D.E.; Mediellín-Azuara, J.; Lund, J.K.; Howitt, R.E. Hydro-economic models: Concepts, design, applications, and future prospects. J. Hydrol. 2009, 375, 627-643. [CrossRef]

9. Jury, W.A.; Vaux, H.J. The emerging global water crisis: Managing scarcity and conflict between water users. Adv. Agron. 2007, 95, 1-76. [CrossRef]

10. Berger, T.; Birner, R.; Díaz, J.; McCarthy, N.; Wittmer, N. Capturing the complexity of water uses and water users within a multi-agent framework. Water Resour. Manag. 2007, 21, 129. [CrossRef]

11. Madani, K.; Lund, J.R. A Monte-Carlo game theoretic approach for multi-criteria decision making under uncertainty. Adv. Water Resour. 2011, 34, 607-616. [CrossRef]

12. Brown, C.M.; Lund, J.R.; Cai, X.; Reed, P.M.; Zagona, E.A.; Ostfeld, A.; Hall, J.; Characklis, G.W.; Yu, Y.; Brekke, L. The future of water resources systems analysis: Toward a scientific framework for sustainable water management. Water Resour. Res. 2015, 51, 6110-6124. [CrossRef]

13. Sordo-Ward, A.; Granados, I.; Iglesias, A.; Garrote, L. Blue Water in Europe: Estimates of Current and Future Availability and Analysis of Uncertainty. Water 2019, 11, 420. [CrossRef]

14. Granados, A.; Sordo-Ward, A.; Paredes-Beltrán, B.; Garrote, L. Exploring the Role of Reservoir Storage in Enhancing Resilience to Climate Change in Southern Europe. Water 2021, 13, 85. [CrossRef]

15. Li, T.; Qiu, S.; Mao, S.; Bao, R.; Deng, H. Evaluating Water Resource Accessibility in Southwest China. Water 2019, 11, 1708. [CrossRef] 
16. Wang, G.; Xiao, C.; Qi, Z.; Liang, X.; Meng, F.; Sun, Y. Water Resource Carrying Capacity Based on Water Demand Prediction in Chang-Ji Economic Circle. Water 2021, 13, 16. [CrossRef]

17. Rubio-Martin, A.; Pulido-Velazquez, M.; Macian-Sorribes, H.; Garcia-Prats, A. System Dynamics Modeling for Supporting Drought-Oriented Management of the Jucar River System, Spain. Water 2020, 12, 1407. [CrossRef]

18. Gabriel-Martin, I.; Sordo-Ward, A.; Santillán, D.; Garrote, L. Flood Control Versus Water Conservation in Reservoirs: A New Policy to Allocate Available Storage. Water 2020, 12, 994. [CrossRef]

19. Bejarano, M.D.; García-Palacios, J.H.; Sordo-Ward, A.; Garrote, L.; Nilsson, C. A New Tool for Assessing Environmental Impacts of Altering Short-Term Flow and Water Level Regimes. Water 2020, 12, 2913. [CrossRef]

20. Martin-Candilejo, A.; Santillán, D.; Garrote, L. Pump Efficiency Analysis for Proper Energy Assessment in Optimization of Water Supply Systems. Water 2020, 12, 132. [CrossRef]

21. Xie, C.; Yang, Y.; Liu, Y.; Liu, G.; Fan, Z.; Li, Y. A Nation-Wide Framework for Evaluating Freshwater Health in China: Background, Administration, and Indicators. Water 2020, 12, 2596. [CrossRef]

22. Salehi, M.; Aghilinasrollahabadi, K.; Salehi Esfandarani, M. An Investigation of Stormwater Quality Variation within an Industry Sector Using the Self-Reported Data Collected under the Stormwater Monitoring Program. Water 2020, 12, 3185. [CrossRef]

23. Duan, M.; Du, X.; Peng, W.; Zhang, S.; Yan, L. Necessity of Acknowledging Background Pollutants in Management and Assessment of Unique Basins. Water 2019, 11, 1103. [CrossRef]

24. Qi, Z.; Kang, G.; Wu, X.; Sun, Y.; Wang, Y. Multi-Objective Optimization for Selecting and Siting the Cost-Effective BMPs by Coupling Revised GWLF Model and NSGAII Algorithm. Water 2020, 12, 235. [CrossRef]

25. Wang, K.; Zhang, L.; Zhang, L.; Cheng, S. Coupling Coordination Assessment on Sponge City Construction and Its Spatial Pattern in Henan Province, China. Water 2020, 12, 3482. [CrossRef]

26. Lima-Quispe, N.; Coleoni, C.; Rincón, W.; Gutierrez, Z.; Zubieta, F.; Nuñez, S.; Iriarte, J.; Saldías, C.; Purkey, D.; Escobar, M.; et al. Delving into the Divisive Waters of River Basin Planning in Bolivia: A Case Study in the Cochabamba Valley. Water 2021, 13, 190. [CrossRef]

27. Li, Q.; Shangguan, Z.; Wang, M.Y.; Yan, D.; Zhai, R.; Wen, C. Risk Assessment of China's Water-Saving Contract Projects. Water 2020, 12, 2689. [CrossRef]

28. Feria-Domínguez, J.M.; Paneque, P.; de la Piedra, F. Are the Financial Markets Sensitive to Hydrological Risk? Evidence from the Bovespa. Water 2020, 12, 3011. [CrossRef]

29. Shen, C.-C.; Liang, C.-F.; Hsu, C.-H.; Chien, J.-H.; Lin, H.-H. Research on the Impact of Tourism Development on the Sustainable Development of Reservoir Headwater Area Using China's Tingxi Reservoir as an Example. Water 2020, 12, 3311. [CrossRef]

30. Santasusagna Riu, A.; Galindo Caldés, R.; Tort Donada, J. Assessing Inter-Administrative Cooperation in Urban Public Services: A Case Study of River Municipalities in the Internal Border Area between Aragon and Catalonia (Spain). Water 2020, 12, 2505. [CrossRef] 